\title{
CAPITALISM IN CRISIS?
}

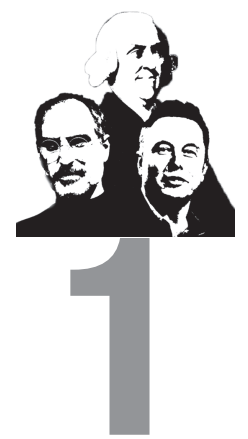

W ithout a shadow of a doubt, capitalism is the single greatest invention in human history. The impact of capitalism on the material progress of mankind dwarfs the impact of the steam engine, electricity, combustible engine, and all other technological breakthroughs combined. Indeed it was raw capitalism, epitomized by larger-than-life titans such as Cornelius Vanderbilt, John Rockefeller, Andrew Carnegie, J.P. Morgan, and Henry Ford, that produced such game-changing breakthroughs. ${ }^{1}$ Yet the central role of capitalism in expanding the sheer amount and variety of goods we enjoy, and in lifting our living standards beyond all recognition, is often underappreciated, if not forgotten altogether. Perhaps this is because we take capitalism for granted, like oxygen, especially after it defeated socialism and became the dominant global economic system. Or, perhaps the lack of appreciation is due to the intangible nature of capitalism, which is not something we can see, touch and feel, unlike the mobile phone, laptop, or internet.

Furthermore, even the most articulate supporters of capitalism usually define their support for capitalism in terms of what they are against - e.g. socialism, excessive government 
interference, stifling bureaucracy - rather than what they are for. Advocates of capitalism usually cite something vague like freedom or liberty, which implicitly refers to freedom or liberty from the government. But there is, in fact, a crystal-clear intellectual, moral, and common-sense positive case for capitalism. That positive case is that capitalism is ultimately a supremely fair economic system. The essence of capitalism is that each of us is rewarded according to the quality and quantity of our work. Under capitalism, the amount of pie we get to eat depends on the amount of crust and fillings we add to the pie. What can be fairer than that? From this angle, the popular criticism of capitalism as an unfair system is unfounded and puzzling.

Notwithstanding its invaluable contribution to human progress, there is currently a torrential global backlash against capitalism, along with a gathering sense of disillusionment about capitalism. To a large extent, the backlash and disillusionment reflect the public's legitimate concerns about the wide and growing income gap between the rich and the poor, crystallized in Thomas Piketty's bestseller Capital in the Twenty-First Century. It is only natural to blame growing inequality on an economic system that is widely seen as inherently unfair. More generally, there is a disturbing tendency to blame capitalism for all the ills of today's world, from climate change to youth unemployment to Third World poverty. But the capitalist malaise runs much deeper than just unfair perception. Capitalism is, in fact, suffering from an unmistakable loss of momentum - a malaise - and it is no longer the dynamic wealth- and job-creating engine of human progress that it used to be.

Linked to the rise of anti-capitalist sentiment across the world is the rise of anti-globalization

\section{6}

But there is, in fact, a crystal-clear intellectual, moral, and common-sense positive case for capitalism. That positive case is that capitalism is ultimately

a supremely fair economic system. The essence of capitalism is that each of us is rewarded according to the quality and quantity of our work.

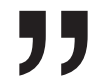


sentiment. A dramatic example of the growing popular anger was Brexit, or the shocking decision of British voters to leave the European Union (EU) in a national referendum held on 23 June 2016. ${ }^{2}$ A number of factors contributed to Brexit, including Britain's traditional reluctance to fully embrace Europe. ${ }^{3}$ But a big factor behind Brexit was the British voters' hostility to immigration and a popular belief that the EU was responsible for immigration. ${ }^{4}$ In other words, Brexit was ultimately a vote against globalization. ${ }^{5}$ Anti-globalization sentiment is by no means limited to Britain. Xenophobic, immigrant-bashing parties such as the National Front in France, led by Marine Le Pen, and Party for Freedom in the Netherlands, led by Geert Wilders, have become major political forces across Western Europe. In Eastern Europe, which ironically receives very few refugees from Syria or other developing countries, refugeebashing has become a surefire recipe for political success, as evident in the enduring popularity of Hungary's populist nationalist leader Viktor Orbán. The frontal assault against globalization is further tightening the full-scale siege of capitalism in the battlefield of public opinion. ${ }^{6}$

Even more shocking than Brexit was the election of Donald Trump as the 45th president of the United States on 8 November 2016. Notwithstanding its significance, Brexit is a tiddling wave compared to Trump's election, which is a gigantic tsunami that sent shock waves throughout the world. Trump, a real estate mogul and former reality TV show star with no political or government experience won a completely unexpected electoral victory over Hillary Clinton, a highly experienced politician with a wealth of government experience. Despite being a rich millionaire, Donald Trump campaigned on an unabashedly populist platform, and claimed to be the champion of
${ }^{2}$ See, for example, "Europe's crisis of faith," TIME magazine, 11/18 July 2016, or "An aggravating absence," The Economist, 2 July 2016, for analysis of Brexit. While the long-term consequences of Brexit are uncertain, the short-run effects were clearly negative, especially for Britain. For example, the pound fell to its lowest level in almost 31 years in the immediate aftermath of the referendum. Prime Minister David Cameron, who staked his political future on the referendum, promptly resigned.

${ }^{3}$ Britain has traditionally looked across the Atlantic to America rather than across the English Channel to the EU, dominated since its inception by France and Germany, as its closest ally and partner.

${ }^{4}$ The EU mandates freedom of movement for EU citizens within the EU. Paradoxically, although significant numbers of citizens from poorer EU countries such as Poland and Slovakia did migrate to Britain for work, the majority of immigrants to Britain are from non-EU countries although the share of EU immigrants has been rising in recent years.

${ }^{5}$ See, for example, "The politics of anger," The Economist, 2 July 2016. Tellingly, London and its suburbs, the most prosperous area of Britain which gained the most from globalization, voted solidly in favor of remaining in the EU. London is one of the world's greatest international financial centers. In stark contrast, the run-down industrial cities of northern England, hit hard by imports from China and elsewhere, voted heavily in favor of leaving the EU.

${ }^{6}$ Almost invariably, anti-capitalism and anti-globalization go hand in hand together. But capitalism and globalization are fundamentally different concepts. Capitalism is a system for organizing the economy while globalization refers to the free flow of goods, services, capital, people, and knowledge and ideas across borders. Of course, there are many close links between the two perhaps the most visible symbols of global capitalism are large multinational companies like McDonald's and CocaCola which operate across the world. Nevertheless, in this book, we will look first and foremost at capitalism. Indeed a meaningful discussion of the pros and cons of globalization would require another entire book! A clear global trend in recent years is the rise of often virulent anti-globalization popular sentiment. This points to a need for governments to make a stronger case for globalization, which benefits the economy and society as a whole, and to make a more concerted effort to help those who lose out from globalization - for instance, workers who lose their jobs due to cheaper imports. See, for example, "The new political divide," The Economist, 30 July 2016. 
the common man forgotten and ignored by the elite. His upset victory was due to a number of different factors, including a widespread sense of alienation among working-class white Americans, shift of the popular mood against immigration and free trade, and hostility at the political establishment in Washington, D.C., personified by Clinton. Since his inauguration in January 2017, President Trump has gradually begun to pursue the anti-free trade and antiimmigration policies he stridently advocated during the election campaign. ${ }^{7}$ It still remains to be seen whether his anti-globalization bite will ultimately match his anti-globalization bark during his presidency, but the signs so far give plenty of cause for concern.

A powerful common undercurrent linking the various ingredients of Trump's success is popular disillusionment about capitalism. America has traditionally been the undisputed leader and bastion of global capitalism. Capitalism, in the best, Adam Smith-ian sense of the word as well as in the entrepreneurial, risktaking, value- and job-creating sense of Steve Jobs and Silicon Valley, has long been identified with America. A defining feature of America has been broad, deep, and genuine support for capitalism among ordinary Americans, not only rich Americans. That support rested on the popular belief that America was a land of opportunity, where anybody with talent, drive and determination, can succeed and move up the social and economic ladder. However, in recent years, worsening inequality and declining social mobility are eroding the very foundations of people's capitalism or democratic capitalism or best-man-wins capitalism. What explains Trump's rise is his ability to capitalize on such disillusionment with capitalism. Increasingly, capitalism is seen as benefiting only a self-perpetuating, hereditary elite while
${ }^{7}$ On 1 March 2018, the Trump administration imposed a $25 \%$ tariff - i.e. tax on imports - on imported steel and $10 \%$ tariff on imported aluminum. On 22 March, the administration announced tariffs on up to US\$60 billion of Chinese imports, including parts and components used in the aeronautics, technology, and energy industries. China responded to the US actions in kind, imposing new tariffs on agricultural and other US imports. A full-fledged trade war between America and China, which may still be averted, will be catastrophic for the world economy. Tellingly, stock markets across the world, including US markets, fell visibly on 23 March 2018, although they subsequently recovered. The Trump administration is re-negotiating the North American Free Trade Agreement (NAFTA), which links the economies of the US, Mexico, and Canada. In addition, it has re-negotiated the US's trade deal with South Korea. At the same time, the Trump administration is making concerted efforts to impose a blanket ban on travel to the US by citizens from six largely Muslim countries, on the grounds that they posed a serious risk to US national security. The ban has been challenged as unconstitutional by US courts but on 4 December 2017, the US Supreme Court ruled that the ban can go into effect, paving the way for implementation. The Trump administration is threatening an end to DACA, or

Deferred Action for Childhood Arrivals, a program established by President Barack Obama that protects 690,000 people who arrived illegally in the US as children from deportation. Those immigrants are known as Dreamers. More broadly, the overall environment in the US has become much less welcoming to immigrants and wouldbe immigrants, including highly skilled ones, since the advent of the Trump administration. 
impoverishing the masses. Trump's political genius was to tap into this revolt of the masses against a capitalism of the elite, by the elite, and for the elite.

Capitalism is, no doubt, far from perfect and must bear some blame for global problems. But our central argument is that it is not capitalism per se but the grotesquely deformed capitalism of the 21st century that is failing. More specifically, capitalism has been hijacked by the financial industry, which is no longer the valuable tool of capitalism that channels capital to entrepreneurs and companies. Instead it has become a self-serving leviathan whose blind pursuit of profit almost wrecked the world economy in 2008. Critically, that greed-crazed frenzy, more frightening than a school of Amazon River piranhas devouring a fish to its bare bones within seconds, was made possible by cozy ties between the financial industry and the government, whose implicit guarantees encourage banks to take undue risk, safe in the knowledge that tax payers will bail them out if things went wrong. ${ }^{8}$ Instead of serving entrepreneurs and firms, many of the financial industry's so-called innovations fatten its own pockets, but add little value to the economy and jeopardize financial stability. The US subprime mortgage crisis of 2008, which morphed into the Global Financial Crisis, underlined the industry's unlimited potential for damage.

But the good news is that there is still plenty of hope for capitalism to return to its roots. Capitalism's current woes do not begin and end with the financial industry. In fact, reforming the financial industry is a good place to start reforming capitalism. The twisted 21 stcentury capitalism of the financial industry dominating the real economy must give way to the original, benign, socially desirable
${ }^{8}$ And, sure enough, things went spectacularly wrong when Lehman Brothers went bankrupt in September 2008, triggering the Global Financial Crisis. As it rightly turned out, the US government honored its guarantee with a multibillion-dollar bailout package for the banks. 
capitalism of the financial industry serving the real economy. Good capitalism is vibrant capitalism in which greed and the profit motive encourage innovative, risk-taking, profit-seeking entrepreneurs to create new and better products, to invest in new and better technologies, and to hire more workers and devote in their training and re-training. Therefore, reinstating the weakened links between the financial industry and the real economy is vital to restoring the health of capitalism. A healthy capitalism, in turn, is crucial to tackling humanity's greatest contemporary challenges, like environmental destruction, youth unemployment and chronic poverty.

At a deeper level, the root cause of capitalism's current slump is stifling government regulation and interference that stands in the way of private enterprise and entrepreneurship. Revamping the financial industry so that it serves the real economy rather than itself is, for sure, a major priority for fixing capitalism. But the bigger priority is to get government and government bureaucrats off the back of private business so that entrepreneurs can take risks and go about doing what they do best - creating useful new products and technologies, jobs, and wealth. Paradoxically, the government was asleep at the wheels when it came to regulating the financial industry, which needs to be tightly regulated, while it was overregulating the real economy and the risk-taking entrepreneurs who create wealth and jobs. In other words, governments were giving a free pass to the likes of hedge funds, which create little social value, while handcuffing the likes of Steve Jobs, who generate plenty of social value.

In truth, capitalism is not even remotely in any slump. What passes for capitalism today, the same capitalism that is widely and unfairly criticized

\section{6}

In other words, governments were giving a free pass to the likes of hedge funds, which create little social value, while handcuffing the likes of Steve Jobs, who generate plenty of social value.

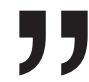


as the root cause of all of mankind's problems, is not capitalism at all. Today's capitalism is so far removed from the benign original vision of Adam Smith - individual greed promoting the social good and driving human progress - that he would barely recognize it if he came back to life. ${ }^{9}$ The visible, meddling, and corrupt hand of the government has pushed aside the invisible, entrepreneurial, and wealth-creating hand of the market. Across vast swathes of the world, the only growth industry is the government industry. But notwithstanding the wishful self-delusion of politicians and bureaucrats, the government industry does not create useful new products and technologies, and it most certainly does not create wealth and jobs. Far worse, government interference suffocates wealth- and job-creating entrepreneurship and brings economic progress to a rude stop.

The runaway growth of the government industry, which squeezes the very life out of the private sector, is indeed cause for deep concern and alarm about the future prospects of capitalism and mankind. No country ever got rich by expanding the government, and no country ever will. Conversely, no country ever got rich by suffocating its private sector. Moreover, the world will not solve its myriad urgent challenges - from climate change and environmental destruction which threaten us and our children and grandchildren, to the inhumane poverty which still enslaves far too many of our fellow global citizens, to the bleak employment prospects of millions of youths in both rich and poor countries - by adding yet more foot soldiers to its already-bulging army of government bureaucrats. Tackling global problems requires less, not more, government, and what the world needs is more, not less, capitalism. Capitalism is not part of the problem, but a central part of the solution.
${ }^{9} \mathrm{His}$ hugely influential 1776 masterpiece The Wealth of Nations is considered the first modern work of economics, and eloquently explains how rational selfinterest and competition fosters economic prosperity. 
Above all, government officials need to get out of the way and allow dynamic, creative entrepreneurs (think of Steve Jobs and his friends starting Apple in a suburban California garage) to work their capitalist magic - taking risks, inventing useful new products and technologies, creating wealth and jobs in the process, and finding innovative solutions to mankind's biggest challenges. For example, environmental destruction and global warming are giving rise to an increased demand for environment-friendly technologies and products. Green demand is growing not only in rich America but also in much poorer China, where millions of people are suffering from some of the worst air quality in the world. Where there is demand, there are profit opportunities. And where there are profit opportunities, there are profit-seeking, risk-taking entrepreneurs. Elon Musk is a prime example of a visionary green entrepreneur and his Tesla electric car is the kind of innovative green product which will move us toward a greener, better future.

At a broader level, much of the blame for capitalism's current malaise lies with the government. Capitalism at its best requires the government to be an honest and competent referee of a fierce but fair, never-ending contest among entrepreneurs and firms. If the government did this well, the winners will be entrepreneurs and firms that create socially valuable products and technologies. Yet far too often, the government does a terrible job of refereeing the competition. For one, unhealthily close ties between government and business mean that the winners are those who are good at cozying up to politicians and bureaucrats, not those who are good at creating social value. The unholy alliance is good for corrupt politicians and bureaucrats, and good for corrupt businessmen,

\section{6}

For example, environmental destruction and global warming are giving rise to an increased demand for environment-friendly technologies and products.... Where there is demand, there are profit opportunities.

And where there are profit opportunities, there are profitseeking, risk-taking entrepreneurs.

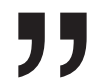


but bad for everybody else and the entire economy. Even worse, the government produces far too many goods and services, even though it tends to be terrible at making things. Last but not least, as already alluded to, bureaucrats often suffocate the private sector with mind-numbing overregulation. Therefore, tweaking the role of the government in the economy must be at the front and center of reforming capitalism.

\section{6}

Capitalism at its best requires the government to be an honest and competent referee of a fierce but fair, never-ending contest among entrepreneurs and firms. If the government did this well, the winners will

be entrepreneurs and firms that create socially valuable products and technologies. 